\title{
Cutaneous Metastases and Right Hemiplegia as First Manifestations of Renal Cell Carcinoma
}

Uriel Villela-Segura', David Herrera-van Oostdam $^{2}$, Reynaldo Falcon-Escobedo ${ }^{3}$, Cesar Daniel Alfaro-Tirado ${ }^{2}$ and Esther GuevaraSangines ${ }^{1 *}$

${ }^{1}$ Department of Dermatology, Hospital Regional “Licenciado Adolfo López Mateos", ISSSTE, México ${ }^{2}$ Department of Internal Medicine, Hospital Central “Dr. Ignacio Morones Prieto", México

${ }^{3}$ Department of Pathology, Hospital Central "Dr. Ignacio Morones Prieto", México

*Corresponding author: Esther Guevara-Sangines, Department of Dermatology, Hospital Regional "Licenciado Adolfo López Mateos", ISSSTE, Mexico City, Av. Universidad 1321, Florida, BO 01030, México

Received: J une 10, 2017; Accepted: July 10, 2017; Published: J uly 24, 2017

\section{Introduction}

Renal Cell Carcinoma (RCC) characterizes for having a wide range of clinical presentations [1]. It is estimated that $50 \%$ of patients present with disseminated disease at diagnosis, the most common affected sites are: lung, liver, bone and brain, being skin a rare affected site, present in $8 \%$ of all cases [1], ensuing a bad prognosis, with a life expectancy of 6 months [3].

\section{Case Presentation}

A previously healthy 83 year old male patient, inmate of a mexican prison whose only risk factor were tobacco exposure, presented in emergency department for sudden right hemiplejia. Physical examination revealed the presence of nine tumors located on right pre-auricular region, external ear and right neck aspect, such neoformations had a size between 0.5 to $5 \mathrm{~cm}$, had a red-bluish color, were lobulated and some of them were ulcerated with a fibrinous cover; such growing masses had a four month evolution and were completely asymptomatic (Figure 1A); patient's relatives managed to obtain a picture taken three months earlier where the patient had just two tumors located on right external ear and right neck aspect (Figure 1B).

Blood and urinary tests were normal. Brain CT-Scan showed a left hemisphere isodense lesion with considerable perilesional edema, suggesting metastasis (Figure 2A); further body CT-Scan revealed a left renal tumor (Figure 2B). After clinical and radiological findings, renal tumor was considered to be causative of both brain and possibly cutaneous metastases; skin biopsy from one of the tumors showed presence of clear cells of pleomorphic nuclei in dermis, having an acinar arrangement (Figure 3A); immunochemistry and resulted positive for Vimentin (Figure 3B), CD-10 (Figure 3C), RCC (Figure $3 \mathrm{D})$ and $\mathrm{CK}$ AE1/AE3; approaching the clinical and pathological correlation of metastatic renal cell carcinoma. The patient died few days later during his hospitalization.
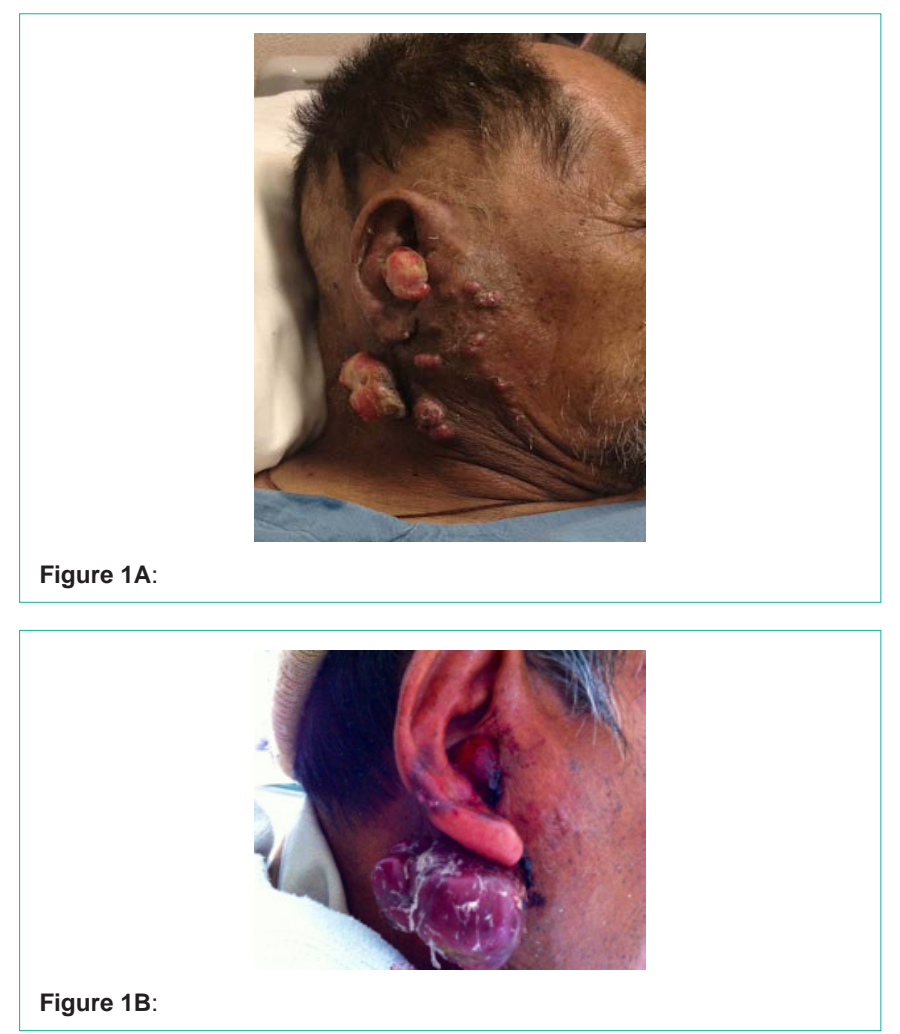

\section{Discussion}

RCC comprises $3 \%$ of all malignant neoplasias, having predominance on male gender between the sixth and eight decade of life [4]. Risks factors for developing RCC include tobacco exposure, obesity, genetic factors as Von Hippel-Lindau disease and previous exposure to chemotherapy. Cutaneous metastases from RCC are frequently present in patients with previous history of such
Ann Hematol Oncol - Volume 4 Issue 8 - 2017 ISSN : 2375-7965 | www.austinpublishing group.com Guevara-Sangines et al. (C) All rights are reserved
Citation: Villela-Segura U, Herrera-van Oostdam D, Falcon-Escobedo R, Alfaro-Tirado CD and GuevaraSangines E. Cutaneous Metastases and Right Hemiplegia as First Manifestations of Renal Cell Carcinoma. Ann Hematol Oncol. 2017; 4(8): 1164. 


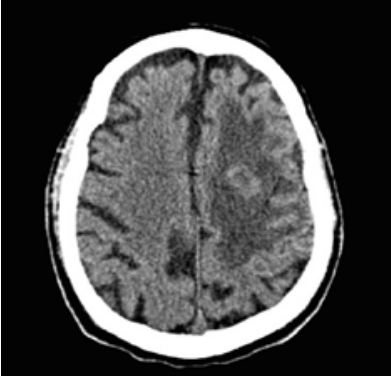

Figure 2A:

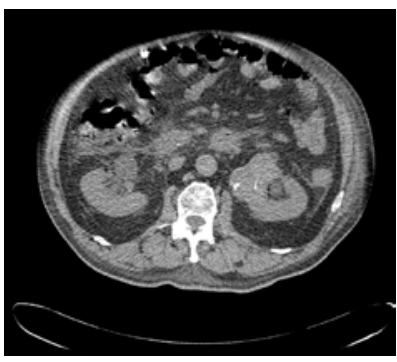

Figure 2B:

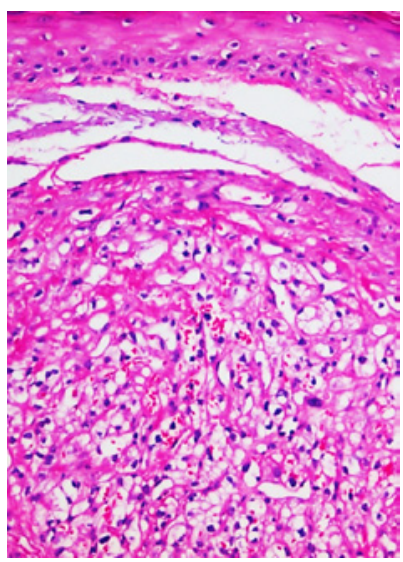

Figure 3A:

malignancy, being exceptional the reported cases in which skin affection was first clinical manifestation [5]. Cutaneous metastases from RCC are usually located in head however that can be found in thorax and upper limbs; most of them are unique described as a rapid growing tumor, red-bluish, lobulated, of well defined edges, ulcerated at times [6].

The estimated time between renal tumor appearance and skin affection is estimated from 12 months to 63 months [7]. As with this patient the majority of RCC cases do not present typical triad consisting in hematuria, palpable tumor and flank mass, present in less than $10 \%$ of all cases [8]. Metastatic RCC engage bad prognosis even with novel chemotherapies as Nivolumab or Everolimus, with a life expectancy of 25 months and 19.6 months respectively [9].

Histologically $85 \%$ of renal cancer cases correspond to clear cell variety, characterized for presenting with cells of translucent big cytoplasm with pleomorphic nuclei located in dermis [10].
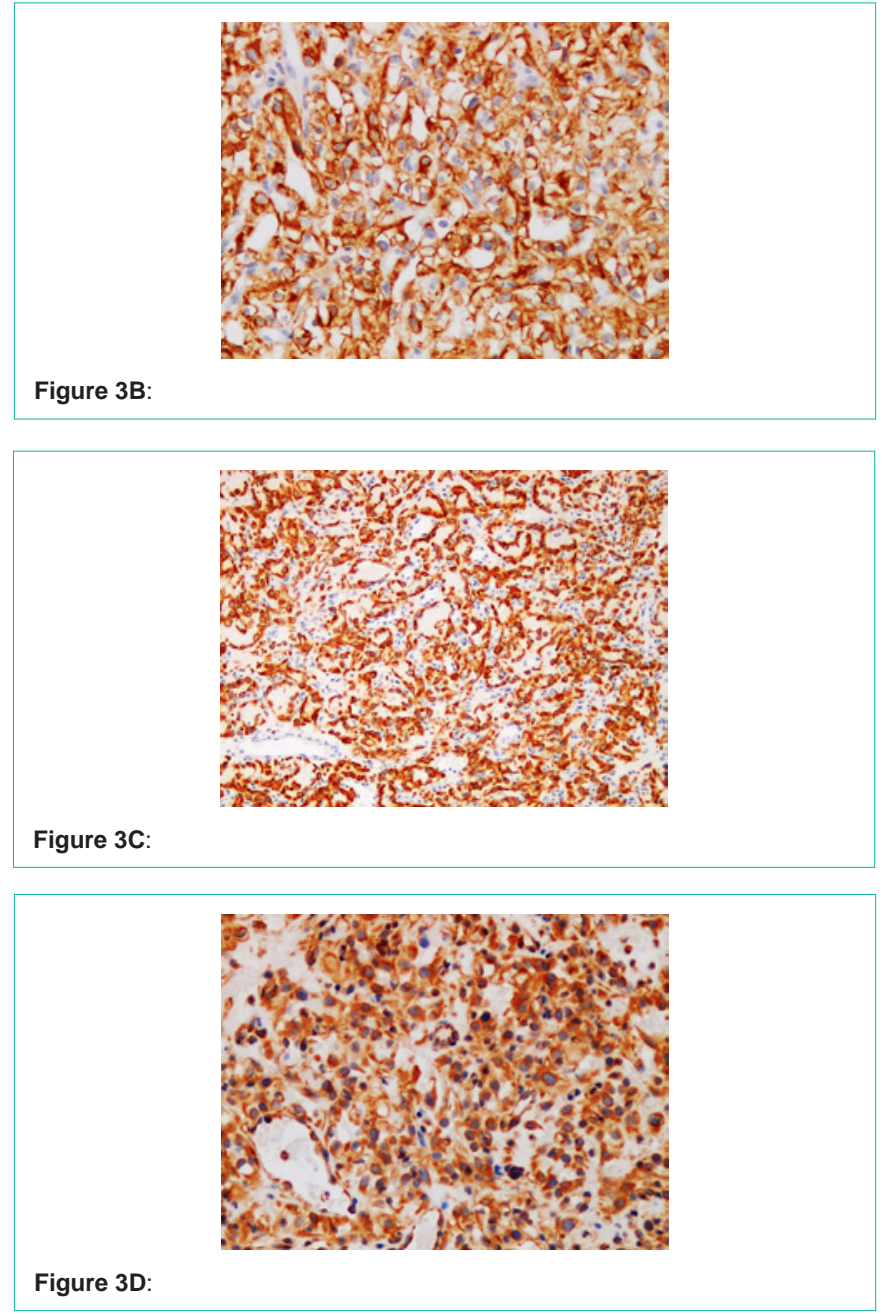

Immunochemistry is positive for Vimentin in $87-100 \%$ of all cases; CD-10, a marker expressing in clear cell surface, positive in $94-100 \%$; RCC a marker present in clear cell renal carcinoma, present in $85 \%$; CK AE1/AE3 marker of renal malignancies in 35\% [11].

As a difference of what has been published in medical literature of cutaneous metastases of RCC, our patient first showed skin lesions followed by neurologic affection without known history of renal malignancy; it was until the clinical-radiological-histological correlation was done, diagnosis was made.

\section{Conclusion}

RCC has a wide clinical presentation, and cutaneous metastases aren't the exception, denoting a perfect example with such unpredictable disease. Clinicians most be aware and more open minded of the wide and polymorphic affections that can be present whereas is a patient with history of this malignancy as for a patient without.

\section{References}

1. Williams JC, Heaney JA. Metastatic renal cell carcinoma presenting as a skin nodule: case report and review of the literature. J Urol. 1994; 152: 2094-2095.

2. Barbagelata López A, Ruibal Moldes M, Blanco Díez A, Enrique Fernández Rosado, Jose Luis Ponce Díaz-Reixa, Serafín Novas Castro, et al. Cutaneous metastasis of a renal carcinoma: case report and review. Arch españoles 
Urol. 2005; 58: 247-250.

3. Lim C, Chan R, Regan W. Renal cell carcinoma with cutaneous metastases. Australas J Dermatol. 2005; 46: 158-160.

4. Gül U, Kiliç A, Gönül M, Külcü Cakmak S, Erinçkan C. Spectrum of cutaneous metastases in 1287 cases of internal malignancies: a study from Turkey. Acta Derm Venereol. 2007; 87: 160-162.

5. Peris K, Fargnoli MC, Lunghi F, Chimenti S. Unusually large cutaneous metastases of renal cell carcinoma. Acta Derm Venereol. 2001; 81: 77-78.

6. Kouroupakis D, Patsea E, Sofras F, Apostolikas N. Renal cell carcinoma metastases to the skin: a not so rare case? Br J Urol. 1995; 75: 583-585.

7. Porter NA, Anderson HL, Al-Dujaily S. Renal cell carcinoma presenting as a solitary cutaneous facial metastasis: case report and review of the literature. Int Semin Surg Oncol. 2006; 3: 27.
8. Motzer RJ, Escudier B, McDermott DF, George S, Hammers HJ, Srinivas S, et al. Nivolumab versus Everolimus in Advanced Renal-Cell Carcinoma. N Engl J Med. 2015; 373: 1803-1813.

9. Perna AG, Ostler DA, Ivan D, Lazar AJ, Diwan AH, Prieto VG, et al. Renal cell carcinoma marker (RCC-Ma) is specific for cutaneous metastasis of renal cell carcinoma. J Cutan Pathol. 2007; 34: 381-385.

10. Miolo G, Ash A, Buonadonna A, Giovanni Lo Re, Elena Torrisi, Silvia Cervo, et al. Grade 4 unclassified renal cell carcinoma with sarcomatoid component expressing S-100 protein. A case report with peculiar diagnostic and therapeutic implications. Cancer Biol Ther. 2014; 15: 1439-1443.
Ann Hematol Oncol - Volume 4 Issue 8 - 2017

ISSN : 2375-7965 | www.austinpublishinggroup.con

Guevara-Sangines et al. (c) All rights are reserved
Citation: Villela-Segura U, Herrera-van Oostdam D, Falcon-Escobedo R, Alfaro-Tirado CD and GuevaraSangines E. Cutaneous Metastases and Right Hemiplegia as First Manifestations of Renal Cell Carcinoma. Ann Hematol Oncol. 2017; 4(8): 1164. 